\title{
Long-term monitoring of the dredged material deposit sites in the Eastern Gulf of Finland
}

\author{
Alexander Chusov ${ }^{1}$, Mikhail Shilin ${ }^{2,}$, George Gogoberidze ${ }^{3}$, Nikolai Bobylev $^{2}$, Alexandra \\ Ershova $^{4}$, and Julia Lednova ${ }^{1}$ \\ ${ }^{1}$ Peter the Great Polytechnic University, Polytechnicheskaya str., 29, 195251, St. Petersburg, Russia \\ ${ }^{2}$ St. Petersburg State University, Universitetskaya Emb., 7-9, 199034, St. Petersburg, Russia \\ ${ }^{3}$ Murmansk Arctic State University, Kapitana Egorova str., 15, 183038, Murmansk, Russia \\ ${ }^{4}$ Russian State Hydrometeorological University, Voronezhskaya str., 79, 192007, St. Petersburg, \\ Russia
}

\begin{abstract}
The goal of the paper is summarizing the results of the 20 -years monitoring of the deposit sites of the dredged material in the Eastern Gulf of Finland (EGoF) and in the Neva Bay. The biotic and abiotic components of deposit sites ecosystems were observed there in 1999-2019, with using standard monitoring methods, in order to reveal effects of dumping on hydrobiologic communities and to determine their environmental status. The Biota Condition Index for 6 deposit sites was calculated and compared to areas which are not stressed by dumping. It is shown that the biological communities (especially - benthic) in the deposit sites areas are enormous not-sustainable and start their succession from the zero point every time after repeating stressing effect of dumping.
\end{abstract}

\section{Introduction}

On the base of the results of investigations, which took place during 20 years in the coastal zone of the Eastern Gulf of Finland (Baltic Sea) and Neva Bay, the environmental effects of the dumping of the dredged material on the ecosystems of the underwater bottom deposit sites were analysed. In 1999-2019 the program of the Ecological Monitoring of Underwater Deposit Sites (EM UDS) for the Eastern Gulf of Finland and Neva Bay was developed and used [1-9]. Principal questions and goals of the EM UDS are: (1) revealing of the short- and long-term environmental effects of the dumping of the dredged material, and establishing the difference between the natural and anthropogenic trends of the coastal ecosystems near the dredged material deposit sites; (2) estimation of reversibility / irreversibility of trends and changes in coastal ecosystems due to influence of the dumping of dredged material; (3) finding the ways of minimizing and compensation of negative effects on the coastal environment $[3,4,10-15]$.

\footnotetext{
*Corresponding author: shilinspb@gmail.ru
} 


\section{Materials and methods}

6 underwater deposit sites were studied in the Eastern Gulf of Finland (fig. 1): (1-2) in front of the Southern Lakhta and Northern Lakhta, where uncontrolled dumping of the dredging material was fixed, (3) near the Tolboukhin lighthouse; (4) to the south of the Bolshoy Berezoviy island; (5) Grouzniy island and (6) Luga bay. The most stressing effects of the dredging projects are the following: (1) increase of suspended material in the water, and (2) destruction of the bottom biotopes. The effect of the uncontrolled anthropogenic activity on the deposit sites is the general negative influence on the coastal environment, including change and destruction of coastal morphology, pollution of marine waters and sediments, changes in the composition of hydrobiologic communities and growing down of fish stocks.

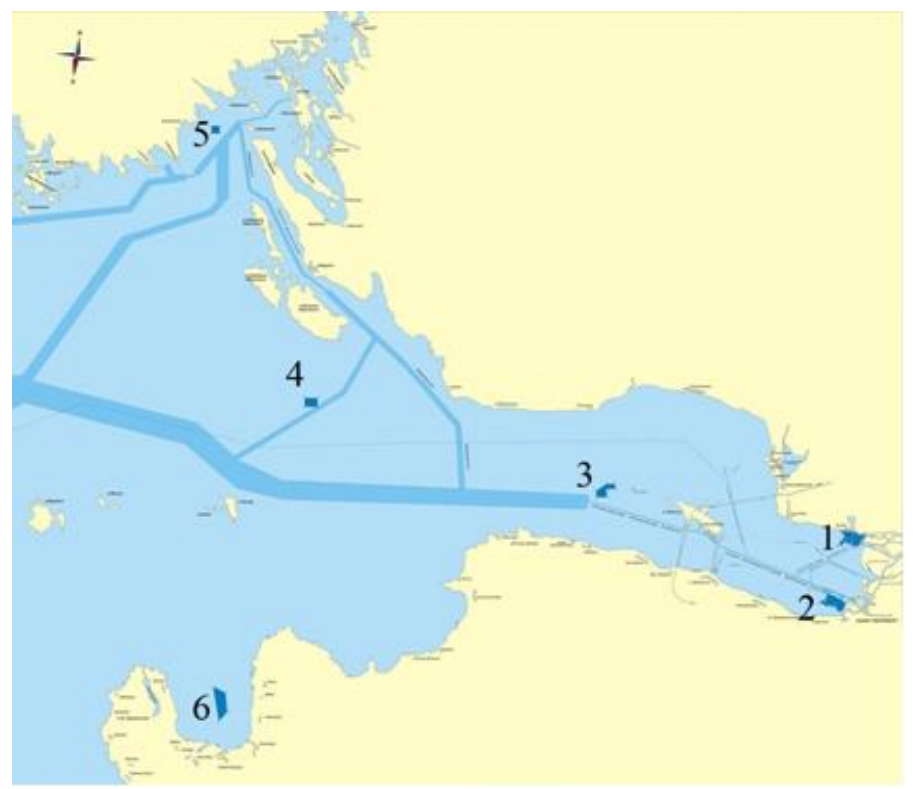

Fig. 1. Underwater deposit sites in the Eastern Gulf of Finland and in the Neva Bay.

\section{Field study}

Field studies in the form of EM UDS program in the Eastern Gulf of Finland and Neva Bay were carried out since 1999 by expert team specialists [1-10, 12]. The measurements of oceanographic parameters were made:

- temperature and salinity - by CTD-90m (U.S. production);

- the currents - by autonomous vector-averaging current measurer «Vector-2»;

- water transparency - by Secchi disk.

Samples were taken with using the following devices:

- Molchanov water sampler for water sampling for hydrochemical analysis;

- «Ocean small scoop» for sampling of bottom sediments and benthic communities.

Samples of sediments were collected in standard glassware and special packages for the soil. Samples of benthic communities were washed behind the vessel and placed in special packages for the soil, too.

In laboratory the benthic samples were analyzed as environmental condition indicators of underwater deposit sites. In each sample the benthic organisms were obtained from 
ground, sorted, computed and weighted on electronic scales VLT-150-P up to $0.001 \mathrm{~g}$. Organisms were weighted by basic taxonomic groups. Hydrobionts' species identification was made by using a microscope (MIKMED) and binocular (MBS-10).

Maximal influence of environmental factors on the conditions of the benthic communities in the underwater deposit sites areas was detected on the base of field research. Assessment of the ecological situation in these areas was made by using of Biota Condition Index [10].

Biota Condition Index was calculated as:

$$
I=\left(N_{d s}: N_{s t}\right) * 100 \%
$$

where $I$ - Biota Condition Index (BCI);

$N_{d s}$ - numbers of hydrobiological organisms near underwater bottom deposit site, thousand individuals per square meter;

$N_{s t}$ - numbers of hydrobiological organisms in the «reference site for comparison» out of the deposit site boundaries, thousand individuals per square meter.

\section{Results}

\subsection{Abiotic conditions}

The bottom sediments of different parts of Eastern Gulf of Finland and Neva Bay have significant difference in grain-size distribution. For the central part of Neva Bay the clayey argillaceous of aleurite are typical, and for the north-eastern part of Neva Bay - the finegrained sands. For the Eastern Gulf of Finland, in general, soft sediments are typical.

The regime of currents of the Eastern Gulf of Finland in the different parts is varied. If the currents have a strong western direction, then fine-grained particles can be transported to the Finland State boundaries, what means a transboundary sediment transport. Fig. 2 shows the satellite picture of transboundary turbidity zone in the Eastern Gulf of Finland, appeared as a result of dredging works.

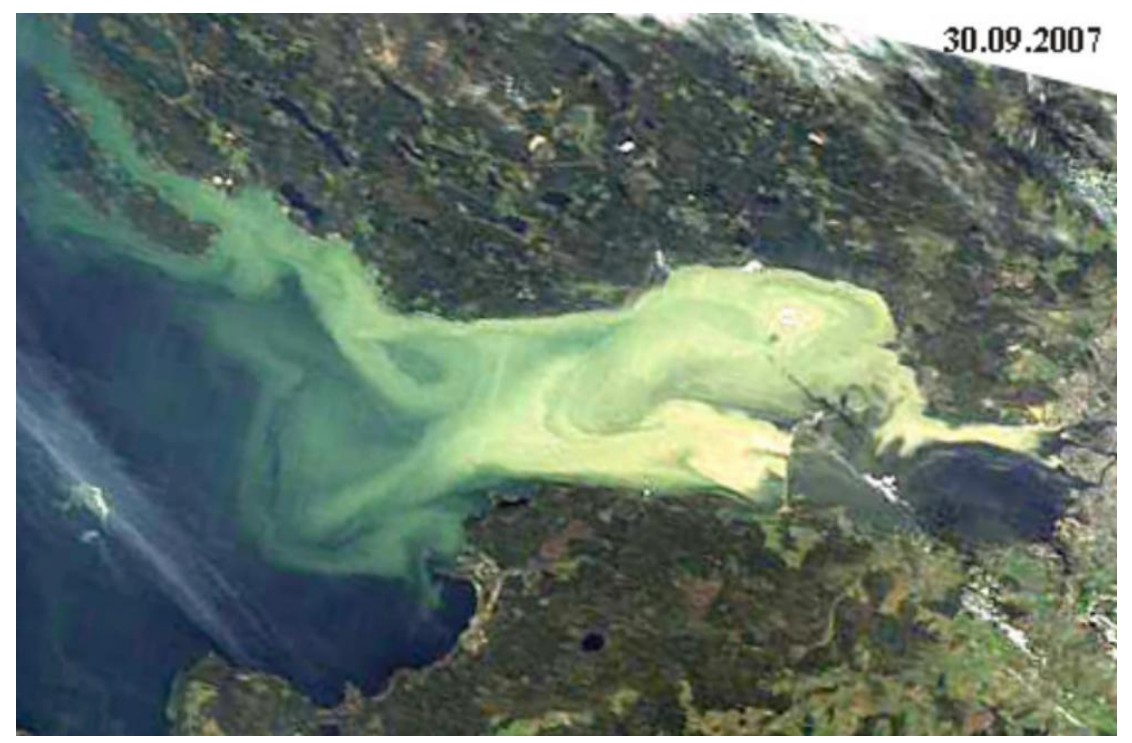

Fig. 2. Satellite picture of sediment spreading, provoked by dredging works (30.09.2007). 
The increasing of suspended material has a strong influence on the biotic communities.

The bottom relief of the Neva Bay was formed as a result of combination of environmental and anthropogenic activities. Old underwater sand mining carriers presently are used as deposit sites for dredging material. Irregular shape of sea bottom is complicating a control of the fullness degree of the dredged material deposit sites.

The topography and the sedimentary cover in the bottom of the North and South Lakhta were transformed by man-made processes completely. A career depth of 10-12 m and outcrops of sandy strata were formed as a result of underwater sand mining.

Residual areas with depth less than $3 \mathrm{~m}$ of underwater deposit sites of Northern and Southern Lakhta were defined by using side-scan sonar. By the results of measurements schematic maps, the differences between the actual depths of the deep space and the benchmark ( $3 \mathrm{~m}$ for underwater bottom deposit sites in the Northern and Southern Lakhta) were revealed.

Calculation of overflow capacity and residual capacity for deposit sites in Northern and Southern Lakhta are shown in table 1. There is majority excess of designed level for Northern and Southern Lakhta.

Table 1 has shown that overflow areas and residual capacity of deposit sites were distributed unevenly. Both deposit sites were located in such places where previously extractions of sand were conducted for the reclamation of urban areas and construction. These arrangement dumps were ecologically justified, and it is a part of the program of rehabilitation after cessation of withdrawal of sand.

In accordance with standards, the boundaries of the underwater deposit sites include zone of discharge and dispersion. In this case, dumping zone lies entirely within the boundaries of the deposit site, but the actual dispersion of the suspension zone is extended far to the west. Deposit sites of Northern Lakhta are half-filled, but of Southern Lakhta are filled to one third. Both areas of dumping have extensive shallows and underwater hills, so there are hazards to navigation in that regions.

Table 1. Calculation of overflow capacity and residual capacity for deposit site in Northern and Southern Lakhta.

\begin{tabular}{|c|c|c|}
\hline Deposit site & $\begin{array}{c}\text { Overflow capacity in deposit } \\
\text { site boundaries (depth }<\mathbf{3} \text { m), } \\
\text { million } \mathbf{~ m}^{\mathbf{3}}\end{array}$ & $\begin{array}{c}\text { Residual capacity in deposit } \\
\text { site boundaries (depth }<\mathbf{3 ~ m} \text { ), } \\
\text { million } \mathbf{~}^{\mathbf{3}}\end{array}$ \\
\hline \multicolumn{3}{|c|}{ Northern Lakhta } \\
\hline$+41 \mathrm{~cm}$ & 2.786 & 3.520 \\
\hline$+34 \mathrm{~cm}$ & 2.884 & 3.763 \\
\hline$+27 \mathrm{~cm}$ & 2.393 & 3.015 \\
\hline \multicolumn{3}{|c|}{ Southern Lakhta } \\
\hline$+39 \mathrm{~cm}$ & 1.898 & 6.941 \\
\hline$+40.5 \mathrm{~cm}$ & 1.941 & 6.882 \\
\hline$+42 \mathrm{~cm}$ & 1.985 & 6.823 \\
\hline
\end{tabular}

Depending on average hydrometeorological conditions, the spread of turbidity water plumes from Northern and Southern Lakhta deposit sites were multiply exceeded such from the bank of Tolboukhin lighthouse. In the first case turbidity water are risen immediately to 
the coast; in the second case the possibilities of such situation can appear only in specific meteorological conditions.

\subsection{Status of biological communities}

There are a lot of Oligochaetes with poor biomass in Northern Lakhta, and a general poor diversity of benthos. Mollusks settlements were found only in the Southern Lakhta, with major biomass and a low diversity. More biodiversity was found near Tolboukhin lighthouse with major biomass of Polychaetes. Results of investigations are shown on figures 3-4.

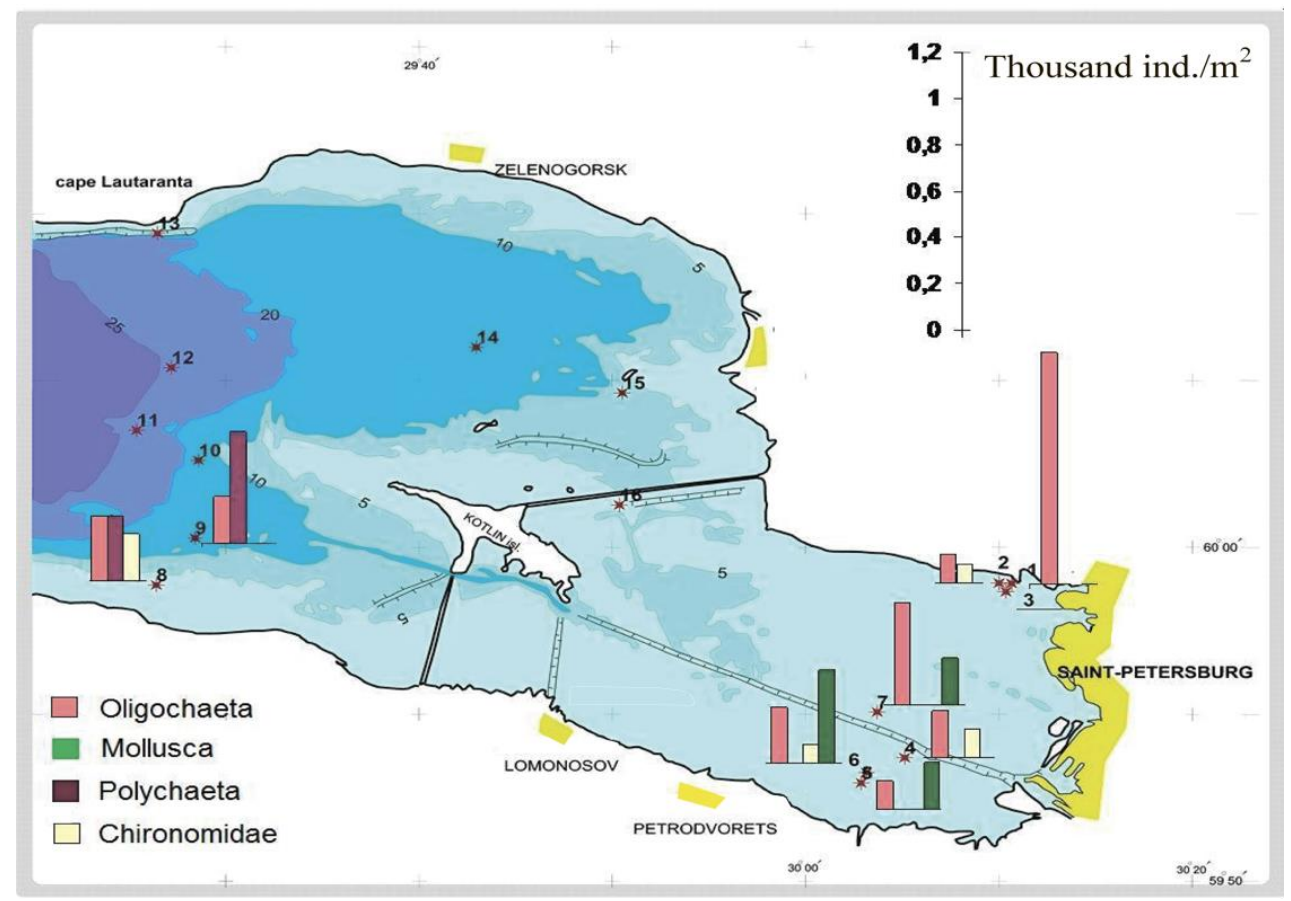

Fig. 3. Numbers of individuals of benthic communities on three underwater deposit sites: Northern Lakhta, Southern Lakhta and Tolboukhin lighthouse.

Underwater bottom deposit sites near Grouzniy island and to the south of the Bolshoy Berezoviy had another situation in benthic species: the biodiversity is poor, and dominants are Polychaetes, what means a bad ecological situation.

The Biota Condition Index BCI for 6 deposit sites was calculated, with comparison to «standard areas», not stressed by dumping. Polichaetes dominated in inlet and outlet parts on the Eastern Gulf of Finland. Molluscs dominated only on the one station - Northern Lakhta, in the Neva Bay. Generally, the BCI was low. The status of benthic communities was estimated as «bad» and «catastrophic» for majority of stations. Results of assessment are shown in table 2 . 


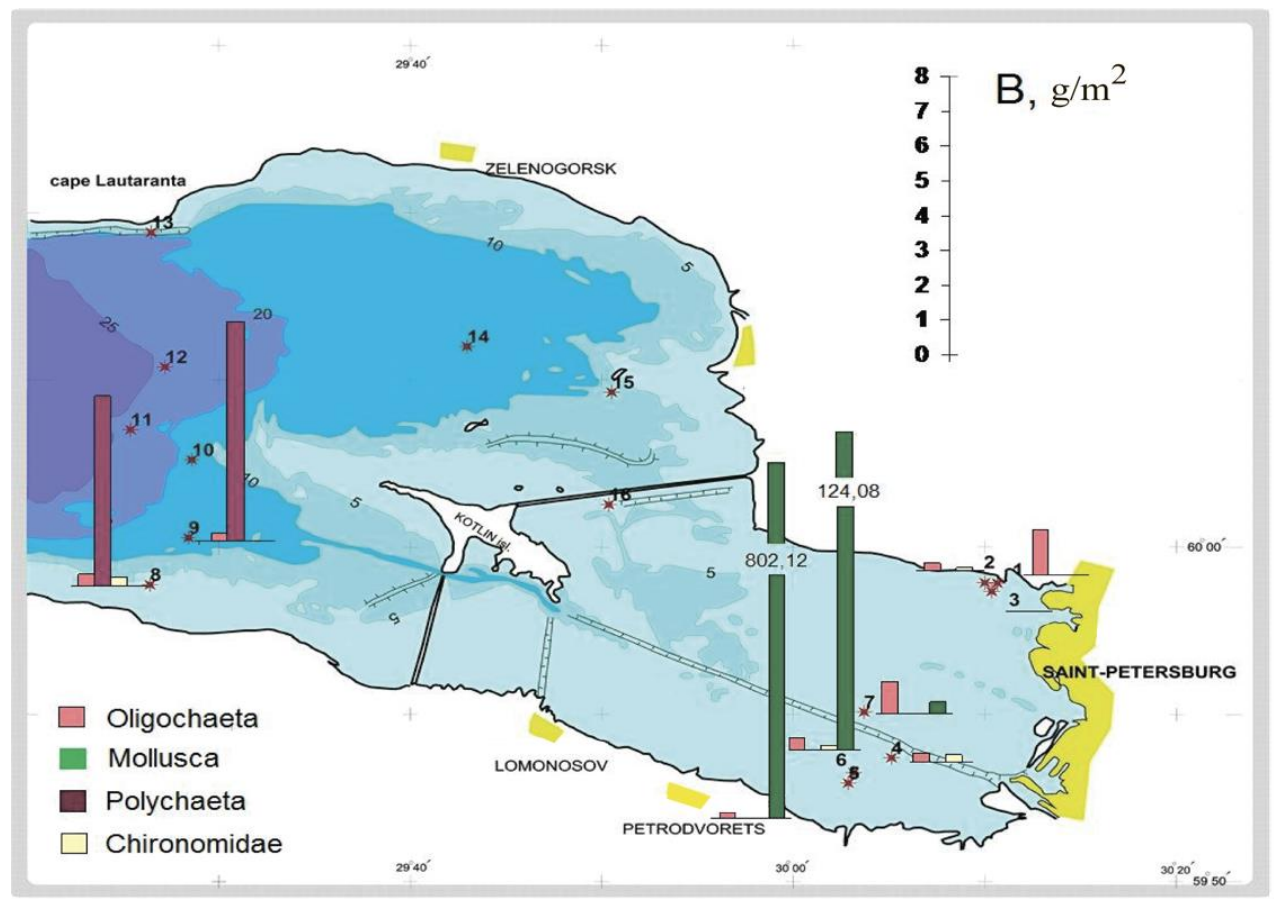

Fig. 4. Biomass of benthic communities near three underwater deposit sites: Northern Lakhta, Southern Lakhta and Tolboukhin lighthouse.

Table 2. Numbers (N, thousand speciments $/ \mathrm{m}^{2}$ ) and biomass $\left(\mathrm{B}, \mathrm{g} / \mathrm{m}^{2}\right)$ of macro-zoobenthos on deposit sites and in the «standard areas».

\begin{tabular}{|c|c|c|c|c|c|}
\hline \multirow{2}{*}{$\begin{array}{l}\text { Deposit } \\
\text { site }\end{array}$} & \multirow{2}{*}{ Predominant } & $\begin{array}{c}\text { Deposit } \\
\text { site }\end{array}$ & $\begin{array}{l}\text { Standard } \\
\text { area }\end{array}$ & \multirow{2}{*}{ I (BCI) } & \multirow{2}{*}{$\begin{array}{l}\text { Qualitative } \\
\text { assessment }\end{array}$} \\
\hline & & $\mathbf{N}$ & $\mathbf{N}$ & & \\
\hline Luga bay & Polychaete & 1.12 & 5.78 & $\begin{array}{c}\mathrm{I}=(1.12: 5.78) \\
100 \%=19 \%\end{array}$ & «Catastrophic» \\
\hline $\begin{array}{l}\text { Gruzniy } \\
\text { island }\end{array}$ & Polychaete & 0.99 & \multicolumn{2}{|c|}{$\begin{array}{l}\text { All stations are under the } \\
\text { influence of dredging site }\end{array}$} & «Bad» \\
\hline $\begin{array}{l}\text { Bolshoy } \\
\text { Berezoviy } \\
\text { island }\end{array}$ & Polychaete & 0.22 & 0.48 & $\begin{array}{c}I=(0.22: 0.48) \\
100 \%=45 \%\end{array}$ & «Bad» \\
\hline $\begin{array}{l}\text { Southern } \\
\text { Lakhta }\end{array}$ & Oligochaete & 0.26 & 0.64 & $\begin{array}{c}I=(0.26: 0.64) \\
100 \%=40 \%\end{array}$ & «Bad» \\
\hline $\begin{array}{l}\text { Northern } \\
\text { Lakhta }\end{array}$ & $\begin{array}{c}\text { Oligochaete, } \\
\text { mollusc }\end{array}$ & 0.16 & 1.00 & $\begin{array}{c}\mathrm{I}=(0.16: 1.00) \\
100 \%=16 \%\end{array}$ & «Catastrophic» \\
\hline $\begin{array}{l}\text { Tolbukhin } \\
\text { lighthouse }\end{array}$ & Polychaete & 0.68 & 0.76 & $\begin{array}{c}\mathrm{I}=(0.68: 0.76) \\
100 \%=89 \%\end{array}$ & «Good» \\
\hline
\end{tabular}

\section{Discussion}

At the present time, in the Neva Bay the underwater deposit sites of Northern and Southern Lakhta are filled above their planned boundaries, which endangers the navigation in the Neva Bay and makes complicated the rehabilitation of the deposit sites after the end of exploitation. There are 77 dumping points both within the official boundaries of dumping sites, and beyond, where the depth is currently less than the minimum designed depth. A 
number of «black» (not permitted) dumping points outside of permitted deposit areas are revealed, and zones of illegal «dumping of dredging material», nearly of the newly constructed avan-port of Bronka, in particular.

On the underwater dumping site in the Tolboukhin bank area, in the Eastern Gulf of Finland, the meteorological conditions form a stable cone formation on the seabed.

Analysis of the used materials confirms the trend of accumulation of heavy metals in sediments. In the zone of underwater dumping of the Neva Bay, where the sorption capacity for metal clay fraction of sediment is almost exhausted, a process of secondary pollution from the bottom layers of heavy metals is observed.

Overall, the quality of the water environment of the Eastern Gulf of Finland and in the Neva Bay can be described as unsatisfactory. Almost everywhere on the deposit sites of dredged material exceeded maximal permissible concentrations of iron, aluminum, manganese, zinc, copper, and at some points - on mercury were found, and the high concentrations of petroleum products.

The basic biotic components of hydrobiologic communities are under stress, what is manifested by follows:

- for phytoplankton - by the dominance of blue-green algae (cyanobacteria);

- for zooplankton - by dramatic reduction of abundance;

- for the macrozoobenthos - by mosaic spatial distribution and instable species composition.

The list of proposals to reduce and prevent the negative impact of dumping in the underwater deposit sites on the natural marine environment can be formulated as:

- analysis and development of recommendations for alternative places of dumping in accordance the HELCOM Guidelines recommendations;

- organization of a system of automatic control over the movement of bottom soils in the areas of human impact (automatic control of the extraction, loading, movement and dumping of soil in the bottom underwater dumps);

- creating a network of automatic marine stations for observation of sea waves, currents and turbidity in the areas of marine dumping sites and the surrounding areas of special environmental sensitivity.

The paper is prepared by the team of GET READY project (Getting Ready for the Cross-Border Challenges: Capacity Building in Sustainable Shore Use) financed by Russia, Finland and EU in the frames of the Cross-border Cooperation Program «South-East Finland-Russia» aimed at support to education, research, technological development and innovation of the region.

\section{References}

1. Ju. Lednova, A. Chusov, M. Shilin, EMRCS 2013 - MEDCOAST 2013 Joint conf. 2, 1024-1034 (2013).

2. M. Shilin, T. Eremina, M. Mamaeva, A. Chusov, J. Lednova, 12th International Conference on the Mediterranian Coastal Environment, MEDCOAST 2015 1, 339-350 (2015).

3. A. Chusov, J. Lednova, M. Shilin, Ocean: Past, Present and Future - 2012 IEEE/OES Baltic International Symposium, BALTIC-2012, (2012). DOI: 10.1109/BALTIC.2012.6249169

4. M.J. Andrianova, K.V. Vorobjev, J.A. Lednova, A.N. Chusov, Appl. Mech. and Mat. 587-589, 653-656 (2014). DOI: 10.4028/www.scientific.net/AMM.587-589.653 
5. V. Badenko, N. Badenko, A. Nikonorov, D. Molodtsov, V. Terleev, Ju. Lednova, V. Maslikov, MATEC Web of Conferences 73, 03003 (2016). DOI: 10.1051/matecconf/20167303003

6. A. Nikonorov, S. Pavlov, V. Terleev, N. Arefiev, V. Badenko, Yu. Volkova, Proc. Eng. 117, 258-263 (2015). DOI: 10.1016/j.proeng.2015.08.160

7. A.A. Maximov, Russ. Jour. of Mar. Biol. 41(4), 300-310 (2015). DOI: 10.1134/S1063074015040094

8. A.A. Maximov, S.M. Golubkov, V.A. Petukhov, Inl. Wat. Biol. 7(4), 372-380 (2014). DOI: $10.1134 /$ S1995082914040099

9. D. Ryabchuk, H. Vallius, V. Zhamoida, A.T. Kotilainen, A. Rybalko, N. Malysheva, N. Deryugina, L. Sukhacheva, Balt. 30(1), 31-46 (2017). DOI: 10.5200/baltica.2017.30.04

10. R.N. Bray, Environmental aspects of dredging (IADC/CEDA, 2008). DOI: 10.1201/9780203894897

11. M. Shilin, A. Ershova, V. Zhigulsky, A. Chusov, V. Abramov, T. Bagrova, N. Popov, 2018 IEEE/OES Baltic International Symposium, BALTIC 2018, (2018). DOI: 10.1109/BALTIC.2018.8634858

12. E. Istomin, V.M. Abramov, V. Burlov, A.Sokolov, .A. Fokicheva, Proceedings of the International Multidisciplinary Scientific GeoConference Surveying Geology and Mining Ecology Management, SGEM 18(2.2), 377-384 (2018). DOI: 10.5593/sgem2018/2.2/S08.049

13. V. Burlov, V.M. Abramov, E. Istomin, A. Fokicheva, A, Sokolov, Proceedings of the International Multidisciplinary Scientific GeoConference Surveying Geology and Mining Ecology Management, SGEM 18(2.2), 483-490 (2018). DOI: 10.5593/sgem2018/2.2/S08.061

14. E. Rumyantseva, G. Gogoberidze, V.M. Abramov, N. Rodin, G. Vladimirova, Proceedings of the International Multidisciplinary Scientific GeoConference Surveying Geology and Mining Ecology Management, SGEM 17(52), $921-927$ (2017). DOI: $10.5593 /$ sgem $2017 / 52 / \mathrm{S} 20.092$

15. A. Isaev, V.M. Abramov, J. Lednova, G. Gogoberidze, O. Khaimina, Proceedings of the International Multidisciplinary Scientific GeoConference Surveying Geology and Mining Ecology Management, SGEM 2(3), 645-652 (2014). DOI: $10.5593 /$ sgem $2014 / \mathrm{b} 32 / \mathrm{s} 15.085$ 